\title{
The Development and Improvement of the Quality System of Audit Services in Latvia
}

\author{
Ludmila Verovska \\ Baltic International Academy, Riga, LV-1019, Latvia \\ *Corresponding Author: mila.v@inbox.lv
}

Copyright (C) 2014 Horizon Research Publishing All rights reserved

\begin{abstract}
Audit activity is a variety of service industries, and cannot be developed independently from the major trends in this area. A strategic direction in the development of audit is creation of the international market of auditing services with unified rules and standards regulating audit, and also creation of uniform quality criteria. This article examines the concept of quality audit service, analyzes the main problems of legislative and methodological character in the area of external and internal audit control in Latvia, and considers opportunities and ways of improvement based on international experience. The research results can be applied to the construction and development of the systems of external and internal audit control, which will be providing the most reliable information about the state of business of companies-customers, their performance and prospects for sustainable development. The financial stability of a company, confirmed by the independent, objective opinion of an auditor, increases the growth of investments, the price of shares, improves the company's reputation in the financial market and ultimately contributes to the stable development of a region.
\end{abstract}

Keyword Quality System of Audit, Quality Requirements, Criteria, Internal and External Quality Control

\section{Introduction}

The article considers the problem of the effective control over the quality of audit services in Latvia, and examines the organization of the system of control at the level of the state, at the level of the national professional association and at the non-governmental level. Based on the analysis of statistical data and national legislation, the factors interfering with the improvement of the quality audit services in Latvia are identified. Research in this area is especially important, as the historical experience of audit in Latvia is rather limited; and there is no sufficient information base for analysis at the level of official statistics, due to the lack of financial resources and awareness of the significance of this service sector to the society.
Today the issue of quality audit services becomes increasingly important. The conditions of crisis increase the information risk, which becomes more dynamic. Users of financial documentation are placing ever greater demands on its accuracy, timeliness and transparency. In these circumstances, more and more attention is paid to the efficiency of the system of control over the quality of auditing services at both international and national levels. In Latvia, the mechanism of quality controlover auditing services at the public and professional levels is still at early stages of development, although some important measures have been taken in the area of legislation. There are now legislative acts that establish requirements to the organization of the system of audit quality control at the levels of state and professional associations as well as at the level of commercial auditor companies. There are also mandatory requirements to conduct quality assurance examinations of audit firms and individual auditors. However, the methodological basis of audit quality control has not been developed sufficiently yet, and the controlling procedure and methods, the criteria of performance evaluation of audit firms, and the public control over audit have not been clarified enough in Latvian official documents.

The purpose of the present research is to develop recommendations for improvements in legislation, methodology, and organization of quality control over auditing services in Latvia.

The object of the research is the system of internal and external control over audit services in Latvia.

The objectives of the research:

- To analyze and evaluate the market of auditing services in Latvia;

- To identify factors influencing its development;

- To identify and describe the concept of audit quality control, its criteria and requirements;

- To study Latvian legislation and other regulations that govern the quality control over audit services, and to identify shortcomings;

- To develop recommendations for improvements in the quality of audit services and the efficiency of internal and external control. 
The methods of the research: grouping, comparison, generalization, description; the methods of analysis and synthesis of economic information: tabular, graphical, expert.

\section{Analysis of the Market for Audit Services}

The dynamics of the market turnover of accounting and consulting services in Latvia has been continuously positive (Figure 1).

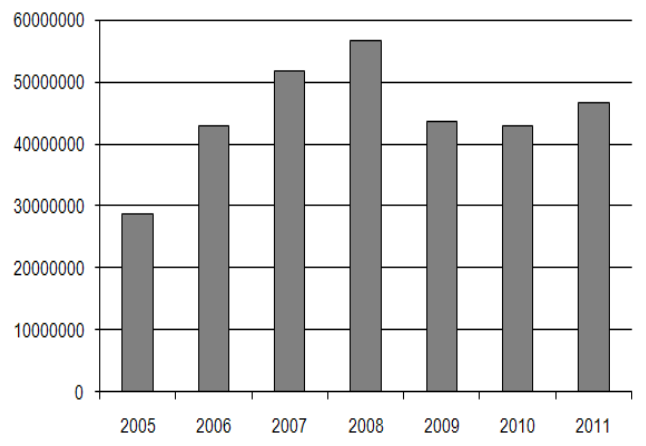

Figure 1. The turnover dynamics of the Latvian market for audit and consulting services in 2005-2011 (in euro), [14]

The most favorable period was in 2008 , when the positive growth was $97 \%$ as compared to 2005 . In 2009 there was a sharp drop in the turnover - by $23 \%$ - due to the economic crisis. In 2011 the situation stabilized. In 2010 the increase was $9 \%$, as compared to 2005 and $62 \%$ as compared to 2011 .

This increase in audit services may be explained by several factors:

- Latvia has become a member state of the EU;

- Gross domestic product has grown, industrial sector and retailing trade have expanded;

- A large number of companies are subject to the mandatory audit because of the low level of criteria in Latvia:

The criteria for mandatory audit are the following: the value of assets should amount to 0.36 million Euros, revenues - 0.71 million Euros, the number of people employed should be 25 .

For comparison, in Lithuania, these figures are much higher: the value of assets should be 1.45 million euro, revenues - 2.9 million euro, number of employees - 50 .

This difference in criteria upsets the balance of competitive environment in the Baltic region, not only in the field of auditing. This also increases the administrative costs of Latvian firms which are not large enough by international standards, but which still have to be audited. The sector of audit services in Latvia is dominated by five major players: Ernst\&Young Baltic; KPMG Baltics; PricewaterhouseCoopers; Deloitte Latvia, Ltd. and Deloitte Audits Latvia, Ltd.; and BDO Invest Rīga, Sworn Advocate Bureau, BDO Zelmenis\&Liberte. Figure 2 shows the market share of auditing services, belonging to each of these companies in the total amount of auditing and consulting services.

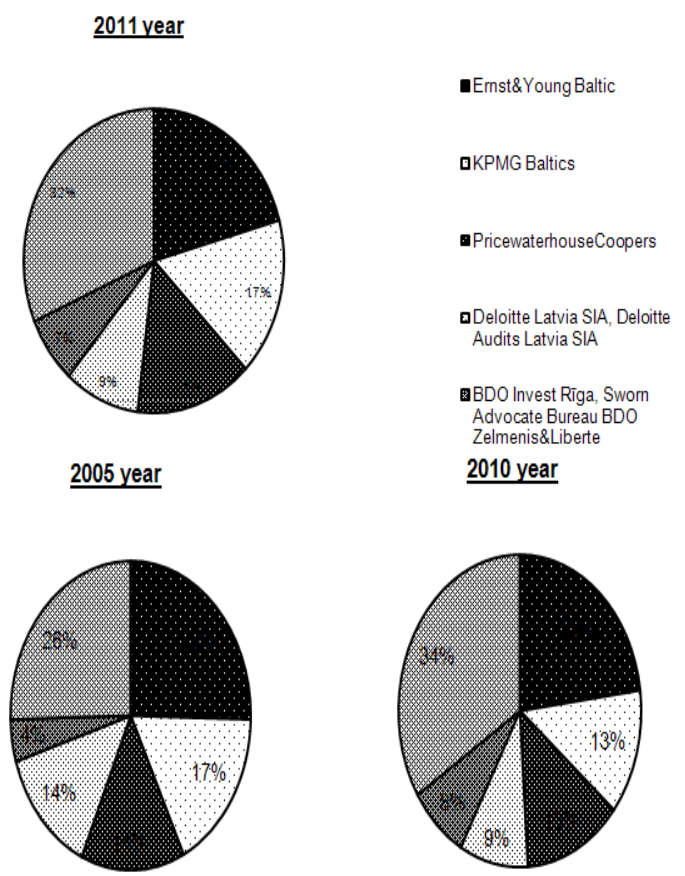

Figure 2. Market shares of five major auditor companies in Latvia in 2005, 2010 and 2011 (\%), [14]

The figure shows that the largest shares of the market were owned by four major international companies and one national company "BDO Invest Rīga". Although in comparison with $2005(75 \%)$ their shares decreased, they still dominated the market. In 2010, their combined share was $66 \%$, and in $2011-68 \%$. The largest share of the market belonged to Ernst \& Young Baltic, which was 23\% in 2010 and $21 \%$ in 2011 . The process of capital concentration has not bypassed the spheres of audit and consulting services, and a high degree of monopolization in the sphere of audit is typical for Latvia as well. A large number of small firms (75\%) with a turnover of less than 120 thousandeuro are simultaneously active on the market of auditing services, which is not conducive to effective control over the quality of their services.

The profit share of these companies was $39.22 \%$ in 2010 , and $46.69 \%$ in 2011 . The percentage of employees in these companies was 37.26 in 2010 and 39.52 in 2011 (Table 1).

The current market structure has established itself in its present form due to several reasons. One of them is that foreign subsidiaries prefer to choose a well-established international auditing company, and sometimes come to the Latvian market, together with already existing connections of its parent company in the field of audit. Another reason refers to a high threshold of insurance costs due to the customers' value of assets, which does not allow domestic companies to participate in the audit of banks, insurance and listed companies. And finally, the scarcity of historical experience of national auditor companies, insufficient financial resources and limited opportunities in the development of their own methodological basis, do not contribute to the development of a national brand with international reputation. 
Table 1. Economic performance of auditor companies for the period of $2010-2011$, [14]

\begin{tabular}{|c|c|c|c|c|c|c|}
\hline & \multicolumn{2}{|c|}{ Turnover (in euro) } & Number of employees & \multicolumn{2}{c|}{ Profit (in euro) } \\
\cline { 2 - 7 } & 2011 & 2010 & 2011 & 2010 & 2011 & 2010 \\
\hline Ernst\&Young Baltic & 9669521 & 9804284 & 49 & 47 & 1006963 & 1592807 \\
\hline KPMG Baltics & 7871429 & 5594140 & 87 & 79 & 412143 & 63357 \\
\hline PricewaterhouseCoopers & 6760227 & 5586109 & 81 & 88 & 656130 & 97739 \\
\hline $\begin{array}{c}\text { Deloitte Latvia SIA, Deloitte Audits } \\
\text { Latvia SIA }\end{array}$ & 4366719 & 3923056 & 60 & 50 & 100087 & -24029 \\
\hline $\begin{array}{c}\text { BDO Invest Rīga, Sworn Advocate } \\
\text { Bureau BDO Zelmenis\&Liberte }\end{array}$ & 3340186 & 3366687 & 51 & 49 & 585784 & 486980 \\
\hline Other & 14710160 & 14585770 & 502 & 527 & 3152419 & 3436210 \\
\hline Total: & 46718241 & 42860046 & 830 & 840 & 5913526 & 5653064 \\
\hline
\end{tabular}

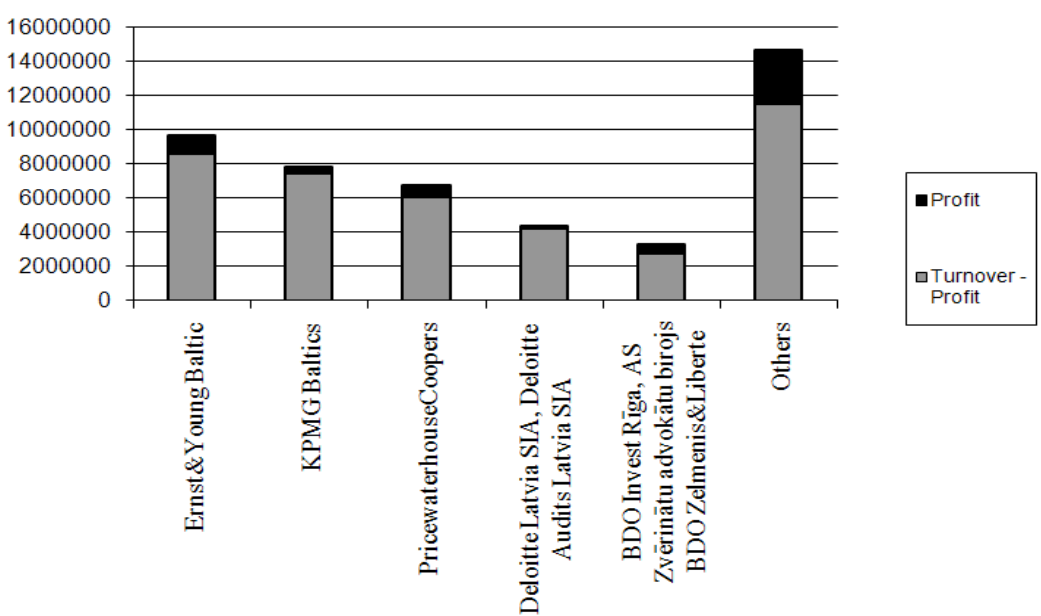

Figure 3. Profit share in the turnover of auditor companies in 2010 (in euro), [14]

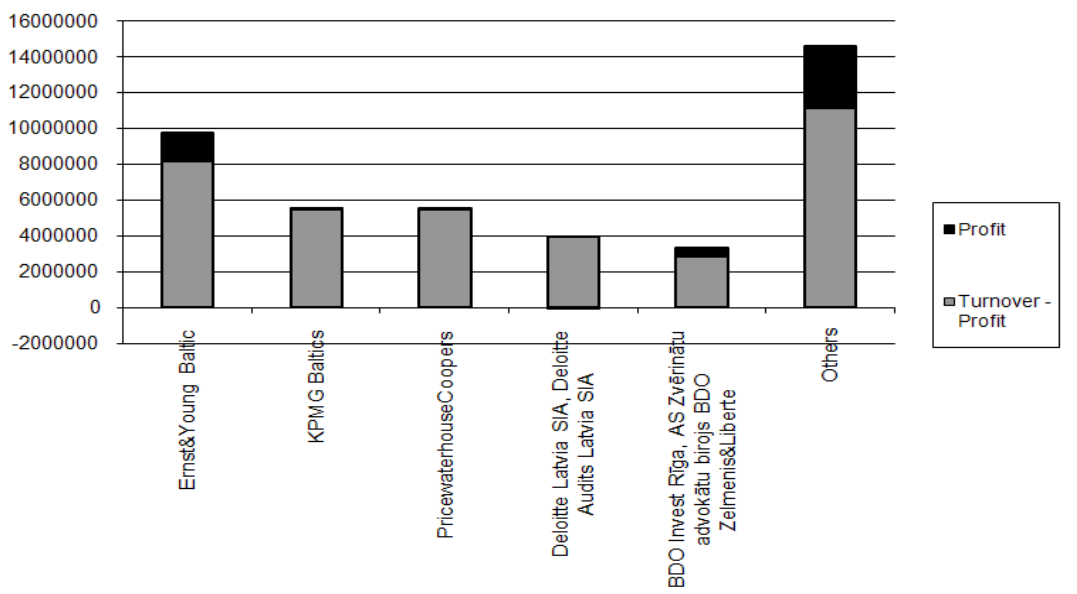

Figure 4. Profit share in the turnover of auditor companies in 2011 (in euro), [14]

Regarding the assessment of profit it should be noted that its share in the overall turnover decreased from $13.19 \%$ to $12.66 \%$ in 2011 as compared to 2010 (Figure 3, Figure 4). This applies to all four international companies. However, local firms worked more efficiently (the firms included in the group designated as "others"). The profit share of "BDO Invest Riga" in 2011 increased to $17.54 \%$ (against $14.46 \%$ in 2010). 


\section{International Regulation of Audit Quality Control}

In the international practice, the basic document that regulates the quality standards of professional services is the statement of membership obligations 1 "Quality assurance" accepted by IFAC (International Federation of Accountants). This document prescribes the requirements to the quality of auditing services performed by the auditors' professional associations. Quality requirements at the level of audit companies are regulated by the International Standard of quality control 1 "Quality control for firms that perform audits and reviews of other assurance and related services engagements“. Quality requirements to individual audit assignments are regulated by the International Standard of auditing 220R "Quality control for audits of historical financial information". For the provision of practical assistance in understanding and application of quality control standards in a particular firm and in accomplishment of a particular assignment, the following document is applied: „JFAC Request for Proposal: Development of a Guide to Quality Control for use by Small and Medium Practices".

\section{Definition of Audit Quality and Its Control as Terms}

The International organization of standardization (ISO) defines quality as a degree of customer's satisfaction. This leads to the conclusion that audit is meant to satisfy the need of the society in reliable financial information.

According to International Auditing Standard N220, a quality audit is the audit conducted in accordance with International Standards on Auditing. Given that international standards have a general nature, it is necessary to clarify the criteria of an expertly conducted high-quality audit. These criteria include the compliance with:

1. International standards of audit and directives of EEK.
2. Regulations of LR Law "On Sworn Auditors".

3. Standards of professional ethics.

4. Terms and requirements of the license.

5. Regulations of LR Cabinet of Ministers and the internal rules of Latvian Association of Certified Auditors.

6. Internal regulations of an auditing company (consistent with international standards and rules of the Association.)

7. Terms of a contract for audit services.

The system of quality control is understood as a system of policies, practices, and procedures adopted by the auditing company so that its management and the society in general had a reasonable assurance that auditing services are performed according to the international standards, codes of professional ethics, regulation documents defining auditing practice in Latvia, and the provisions accepted by the Association of Certified Auditors.

The quality control of auditing services is carried out by methods providing assurance that the company is fulfilling its obligations to its customers in the best way. The quality of audit depends on the organizational structure of the company-auditor and on the choice of auditing procedures that guarantee compliance with generally accepted auditing standards appropriately selected for each client. An appropriate organizational structure includes expert professionals educated in essential features of the client's technological production. Each auditing company should establish policies and procedures of inspection, which will depend on the size of the audited firm, its international and national status, the number of offices and clients, their diversity, and the type of practices.

The quality control should include certain features (Table 2).

The auditing firm should systematize, approve and confirm the principles and procedures of control according to the features of control.

Table 2. Features of audit quality control, [6-8]

\begin{tabular}{|c|c|}
\hline Feature & \begin{tabular}{c} 
Compliance with the quality requirements \\
\hline Independence
\end{tabular} \\
\hline $\begin{array}{c}\text { Professional status } \\
\text { requirements to independence prescribed by the Code of Ethics accepted by LASA } \\
\text { and the Law on "Sworn Auditors". }\end{array}$ \\
\hline $\begin{array}{c}\text { Auditors and other personnel involved in the audit should comply with the } \\
\text { consuilability of } \\
\text { production technology, and have relevant education and expertise. A new } \\
\text { candidate should be approved by a competent, qualified specialist responsible for } \\
\text { the staff. The professional expertise of the staff should be developed on an ongoing } \\
\text { basis. Career promotions should correspond to qualifications. }\end{array}$ \\
\hline $\begin{array}{c}\text { In cases when technical problems concerning the implementation of audit } \\
\text { Policy of control }\end{array}$ & $\begin{array}{c}\text { engagements arise, the participating auditors should have an opportunity to be advised } \\
\text { by relevant qualified professionals. }\end{array}$ \\
\hline Procedures of control & $\begin{array}{c}\text { The policy of control should be observed at each inspection, and at all levels and stages } \\
\text { such as planning, auditing, preparation of the conclusion and reporting to the } \\
\text { management. }\end{array}$ \\
\hline
\end{tabular}

Source: completed by the author on the basis of the Statement on Auditing Standards - SAS, issued by AICPA (American Institute of Certified Public Accountants). 
Table 3. The structure of audit quality control in Latvia

\begin{tabular}{|c|c|c|c|}
\hline Form of control & Subjects of control & Objects of control & Type of control \\
\hline \multirow{2}{*}{ External control } & Ministry of Finance & $\begin{array}{c}\text { Latvian Association of Certified } \\
\text { Auditors, audit firm, certified auditor } *\end{array}$ & $\begin{array}{c}\text { Control over compliance and } \\
\text { efficiency }\end{array}$ \\
\cline { 2 - 4 } & $\begin{array}{c}\text { Association of Certified } \\
\text { Auditors }\end{array}$ & $\begin{array}{c}\text { Audit firm, certified auditor, a separate } \\
\text { audit engagement }\end{array}$ & $\begin{array}{c}\text { Control over compliance, efficiency } \\
\text { and substantive control }\end{array}$ \\
\hline Internal control & Audit firm,certified auditor & A separate audit engagement & $\begin{array}{c}\text { Control over compliance, efficiency } \\
\text { and substantive control }\end{array}$ \\
\hline
\end{tabular}

\section{Oversight and Control of the Activities and Quality of Auditing Services Provided by Certified Auditors and Commercial Auditors' Associations of Latvia}

Matters related to the organization of audit quality control in Latvia are regulated by Article 35 of the "Law on Sworn Auditors". According to this Law, a three-tier system of audit quality control is established in Latvia (Table 3):

- Control on the part of the state is exercised by the Ministry of Finance;

- Control on the part of a professional organization is exercised by Latvian Association of Certified Auditors (LASA);

- Quality control carried out by audit firms and individual certified auditors.

\section{Auditing Services Quality Control Exercised by the State and LASA}

The purpose of quality control is to provide reasonable assurance that an audit firm has created the internal quality control system, adheres to its requirements, and observes professional standards, ethical principles, and legal acts of Latvian Republic. The choice of which entity and how often to check depends on many factors. In practice, two approaches are accepted: time-domain and risk-based. The first approach sets the maximum periodicity of inspections. The second approach takes into account such factors as the number of listed corporate clients, socio-economic value of companies, and the history of violations registered in previous inspections. In Latvia, both approaches are used: the time-domain and risk-based for listed companies.

All commercial companies of sworn auditors and individual sworn auditors are subject to the quality control at least once every five years. Those commercial companies of sworn auditors and sworn auditors that provide services to financial institutions and commercial companies which securities are admitted to the regulated market of the member states are subjected to the quality control at least once every three years.

A quality inspection of auditing services is performed in accordance with regulations approved by LASA in coordination with the Ministry of Finance. A month before the commencement of a quality inspection, LASA notifies the Ministry of Finance which sworn auditors or commercial companies of sworn auditors are subject to inspection no less than once every three years.

According to Paragraph 4, Article 6 of the Law "On Sworn Auditors", the Association of Certified Auditors performs the following functions:

- it provides oversight of compliance with professional standards and ethical principles, as well as other relevant regulations governing the profession, and supervises professional activity of the members of the Association;

- it represents and protects the interests of its members;

- it conducts qualification inspections of sworn auditors;

- it decides on the issuance of certificates to sworn auditors and on granting licenses to commercial companies of sworn auditors;

- it keeps the register of sworn auditors and the register of commercial companies of sworn auditors;

- it adjudicates disputes that may arise between sworn auditors and their clients upon the request of the parties involved;

- it organizes and oversees the professional development of sworn auditors;

Up to date, functional responsibilities of the Latvian Association of Certified Auditors have not included the development and implementation of inspection methodology of the audit conduct.

The standards of audit represent general guidance aimed to guide auditors in the performance of their professional duties. These standards should not be the sole source of guidance for audit practitioners. Taking into account national peculiarities of the audit services market, scant historical experience in the development of audit in Latvia, and the level of foreign languages known by auditors, there is a great demand in the educational and methodological materials, explaining the auditing standards and practices in greater detail.

The Ministry of Finance exercises official state supervision over the Latvian Association of Certified Auditors and cooperates with institutions competent in the field of audit of other member states and third countries. LASA approves all legal documents related to certification, 
licensing, and implementation of other tasks upon agreement with the Ministry of Finance. Direct supervision is exercised by the authorized representatives of the Ministry of Finance. They are entitled to participate in board meetings and general meetings, to get acquainted with the decisions of the association, to request all relevant information, documents and explanations for supervision. The authorized representatives of the Ministry of Finance check the compliance of auditing services with the quality control and prepare a corresponding report at least once a year. They have the right to conduct inspections of the quality control at the place of practice of a certified auditor or a commercial company of sworn auditors, if the client is a financial institution or a commercial company whose securities are admitted to the regulated market of the member states. This right also involves inspection of audit related working papers and the public statements of a sworn auditor or a commercial company of sworn auditors. In order to respect the principle of independence such authorized representatives should meet a number of requirements: they cannot provide auditing services for three years prior to a new job, they cannot be shareholders, nor members of the Board or Council, nor be employed by a commercial company of certified auditors and they shall keep commercial secrets, except in the cases established by the law.

The Cabinet of Ministers (CM) establishes the Auditing Advisory Council. Its goal is to improve the quality of auditing services. The Ministry of Finance, the Ministry of Justice, the Committee of the Market of Finance and Capital, Latvian Association of Certified Auditors, Riga Stock Exchange, the Council of Foreign Investors in Latvia, Latvian Association of Accountants, Latvian Confederation of Employers and one of Latvian higher education institutions, each provide one representative as a member for the Council. The membership of the Council is approved by the CM and the Council acts on the basis of the approved regulations. Its activities are funded from the state budget. The Council considers documents prepared by LASA on the subject of implementation of examinations, certifications, licensing, professional development of certified auditors and quality control. Also the Council studies international auditing standards and ethical principles recognized in Latvia, makes recommendations to LASA for their application and informs the Ministry of Finance. To achieve its objectives the Council has the right to demand information from LASA and the necessary documents, and also may attend LASA meetings and sessions. The Council informs the Ministry of Finance on the performed activities once a year.

The non-governmental oversight of audit quality is rather weak. This is mainly due to the lack of public information, the lack of clear legal regulations to the provision of such information by the Association and commercial companies, and the overall insufficiency of provided information. The law "On Sworn Auditors" demands from sworn auditors to report publicly on their electronic home pages. These reports should provide general information on the main features of the system of internal quality control and the statement of the management on the efficiency of this system, also information on when the last time the external control was conducted. However, this requirement applies only to those auditors, who check listed companies. The Association of Certified Auditors annually provides a report on quality control, which is a mere formality providing just numbers of inspections and numbers of detected violations. This situation is not conducive to public scrutiny and a thorough implementation of the system of audit quality control in the national scale.

\section{Conclusions}

The unsustainable development of Latvian economy, the increase in information risk and the need to attract foreign investments make high demands to the reliability and quality of corporate financial statements, confirmed by professional independent experts. The system of audit quality control depends on many factors, including the degree of development of the national legislation, the techniques and the ability to learn and effectively apply the unified international audit regulations and standards.

The market of auditing services in Latvia is developing, but it has not reached the pre-crisis level yet. This market is characterized by the dominant position of the four largest international companies: Ernst\&Young Baltic; KPMG Baltics; PricewaterhouseCoopers; Deloitte Audits Latvia, Ltd. At the same time a considerable number of small firms are also active on the market of auditing services, which does not result in effective control over the quality of their services.

The article specifies the terms: the system of audit quality control, professional audit and its criteria, elements of quality control.

The analysis of the legislative framework that regulates audit services in Latvia revealed certain deficiencies in the external control at the state level, at the level of the Association of Certified Auditors, and at the level of non-governmental control, which helped to define factors unfavorable to the development of the efficient system of audit quality control.

The system of audit quality inspection and control in Latvia may be improved in the following ways:

- in order to improve and create a modern methodological support of the audit inspection procedure certain amendments should be introduced to LR legislation; Latvian Association of Certified Auditors should be entrusted with the duty to develop software-based methods of audit inspection conduct;

- In order to improve the system of public oversight, the amount of information on violations revealed by the Association should be expanded and not limited only by the description of the number of inspections and the number of detected violations; 
- Latvian Association of Certified Auditors should contribute to the development and improvement of the performance of national companies active in the market of auditing services in Latvia, and help these companies to improve the quality of service by means of effective application of international experience;

- National requirements to auditing services should be developed and applied reasonably, in an objective and impartial way. Specific requirements should not create unnecessary barriers. In this regard, the statutory audit criteria for Latvian companies should be extended to the level accepted in the Baltic region (Lithuania). This will adjust the market of audit services by reducing the number of small firms, and at the same time will allow controlling the quality of audit in a more efficient way.

The improvement of audit quality control will facilitate the promotion of professional services in the Latvian market of auditing services; will enhance professional advancement of auditors and improve their professional reputation; will optimize the auditing services market by way of reducing the number of non bona fide auditor firms; will increase the number of services rendered in the international market; will attract foreign clients with offices in Latvia; will minimize business risk and maximize international investments; will improve business environment and the national image of the country; and on the whole will contribute to the stable development of the national economy.

\section{REFERENCES}

[1] Likums „Par zvērinātiemrevidentiem”, Online available from http://www.likumi.lv

[2] Ministrukabineta 08.06.2004. noteikumi Nr. 525 „Kārtība, kādāiesniedzamipieteikumi un citidokumentizvērināturevidentukvalifikācijaseksāmenukārt ošanai un

zvērināturevidentukomercsabiedrībaslicencessaṇemšanai”, Online available from http://www.likumi.lv

[3] Ministrukabineta 27.12.2001. noteikumi Nr. 547 „Noteikumi par zvērinātarevidenta - pašnodarbinātas personas vaiindividuālakomersanta - un zvērinātarevidentukomercsabiedrībasciviltiesiskāsatbildības apdrošināšanasminimāloatbildībaslimitu", Online available from http://www.likumi.lv
[4] Direktīva 84/253/EEK, Online available fromhttp://eur-lex.europa.eu/LexUriServ/LexUriServ.do?ur $\mathrm{i}=\mathrm{DD}: 17: 01: 31984 \mathrm{~L} 0253: \mathrm{LV}: \mathrm{PDF}$

[5] Direktīva 2006/43/EK, Online available fromhttp://eur-lex.europa.eu/LexUriServ/LexUriServ.do?ur $\mathrm{i}=\mathrm{OJ}: \mathrm{L}: 2006: 157: 0087: 0107: \mathrm{LV}: \mathrm{PDF}$

[6] Statements of Membership Obligations 1 "Quality Assurance", IFAC, 2004, Online available from http://www.ifac.org

[7] International standard on quality control 1 "Quality Control for Firms that Perform Audits and Reviews of Financial Statements, and Other Assurance and Related Services Engagements", IFAC, 2009, Online available from http://www.ifac.org

[8] International Standard on Auditing 220R "Quality Control for Audits Historical Financial Information". Request for proposal: Development of a Guide to Quality Control for use by Small and Medium Practices, IFAC, 2006, Online available from http://www.ifac.org

[9] Alvin A.Arens, Randal J.Elder, Mark S.Beasley. Auditing and Assurance Services an Integrated Approach, Prentice Hal, 13 edition, 2009.

[10] JACKSON R.A. Internal audit in 2020. Internal Auditor, Vol.70. No.6. December 2013. pp.34-41.

[11] Paul Coram, Barry J. Cooper, Philomena Leung, Peter Richardson. Modern auditing and assurance services. 5th ed. Publisher: Milton, Qld : John Wiley, 2011.

[12] Sarowar Hossain. Effect of Regulatory Changes on Auditor Independence and Audit Quality. International Journal of Auditing, Vol. 17, Issue 3, November 2013. pp.246-264.

[13] Internal Control Working Party, Internal Control: Guidance for Directors on the Combined Code. London: The Institute of Chartered Accountants in England \& Wales, 1999.

[14] Адамс Р. Основы аудита, Москва: Финансы и статистика, 2006.

[15] Э.А.Аренс, Дж.К.Лоббек. Аудит, Москва: Финансы и статистика, 5-ое изд., 2003.

[16] Булыга Р.П., Мельник М.В. Аудит бизнеса. Практика и проблемы развития: монография Москва: Юнити-Дана, 2013.

[17] Дефлиз Ф.Л., Дженик Г.Р., О`Рейли В.М., Хирш М.Б. Аудит Монтгомери, Москва: Аудит, ЮНИТИ, 1997.

[18] Latvian information technology company, Online available from http://www.lursoft.lv[accessed on 1th March 2013. 